\title{
The Illegality of Baby Safes as a Hindrance to Women who want to Relinquish their Parental Rights
}

\author{
By Whitney Rosenberg*
}

\begin{abstract}
Child Welfare South Africa estimated that more than 3500 babies were abandoned in South Africa in 2010. 200 babies were estimated in 2010 to be found in Johannesburg and Soweto monthly of which only 60 were found alive. These babies are left for dead in places such as drains, sewers, open fields, rubbish dumps, toilets and dustbins. This problem is not unique to South Africa as recent reports all over the world and more recently in Australia also demonstrate a desperate situation. Although not considered legal, the first baby safes in South Africa were established in July 1999 by Door of Hope Children's Mission at a church in Berea Johannesburg, referred to as the "Hole in the Wall". Some of these organizations operate under major pressure from The Child Welfare Organization to shut their doors even though no one is able to answer the question as to what will happen to the innocent babies if these hatches are closed. In most legal systems abandoning a child is seen as a crime; nevertheless some systems allow legal abandonment that goes beyond giving the child up for adoption. I will start off by examining the intricacies of these laws and conclude by indicating how the introduction of these baby safes in South Africa will save the lives of thousands of babies a year. ${ }^{l}$
\end{abstract}

Keywords: Baby safes, baby boxes, baby abandonment, safe haven laws, anonymous birth, accouchement sous $x$, orphans, babies dumped, United Nations Convention on the Rights of the Child.

\section{Introduction}

The purpose of this study is to examine the legality of baby safe haven laws in France and the United States and to argue for the legality to serve as a motivation for the implementation of these laws in South Africa. I expound on the natures of these laws with a more specific look at the ratification and nonratification of the U.N Convention on the Rights of the Child. As having ratified the Convention, South African law regards the use of baby safe havens as illegal. I illustrate the need for these safe havens to be introduced in South Africa supported by how both ratifying and non-ratifying countries, such as the U.S.A and France, alike have effective laws that save hundreds of babies' lives each year. I further show how South Africa is able to overcome the supposed restrictions placed by the U.N Convention in protecting the child's right to an identity by examining the superior right of the child to life.

\footnotetext{
${ }^{*}$ Lecturer at the University of Johannesburg, Kingsway Campus, Auckland Park, Johannesburg. ${ }^{1}$ A special thank you to my Lord and Saviour Jesus Christ and to all those who assisted me in this article my husband Shannon, Professor Murdoch Watney and Dr Amanda Boniface.
} 


\section{The Legal Position in France and the United States Pertaining to Baby Safe} haven Laws

France ratified The United Nations Convention on the Rights of the Child on the $7^{\text {th }}$ of August $1990^{1}$, which stands as one of the most ratified treaties in history $^{2}$. France has experienced major criticism for its portrayal of the rights of mothers as being superior to those of children. ${ }^{3}$ After seemingly giving the convention no acknowledgment in the realm of child abandonment, French law was pressured into molding the existing laws according to the convention. This issue was finally clarified in the ground breaking case of Odievre $v$ France $^{4}$ by the European Court of Human Rights.

The United States, on the other hand, is not a party to the convention. Although having signed it in 1995 and endorsing its principles, the U.S never committed to being legally bound to it by ratification. Some Republicans fear that its ratification would usurp American sovereignty and undermine parental authority with regard to religious and sex education ${ }^{5}$ and others say there is a 'mere delay' in the process. Whether it be due to delay or fears surrounding implementation, in my opinion one thing is clear, the U.S does not intend on ratifying this convention at any point.

The reasons behind my comparison of the laws of these two countries lie in the fact that both have developed their own system of safe haven laws - on the one hand in the U.S where the emphasis is placed on the situation after the birth and the system of anonymous birth, and on the other in France where the process prior to birth and leading up to birth provides the woman with carefully designed rights and support. My comparison aims to determine the similarities and disparities between the safe haven laws of convention and non-convention countries. It also aims to answer the question: what role should the UN Convention on the Rights of the Child play in the development and consideration of baby safe haven laws or a system of anonymous birth in South Africa?

\section{The Emergence of Baby Safe haven Laws in France and the U.S.A}

The system of anonymous birth in France was started in 1638 by Saint Vincent de Paul, who introduced a revolving crib referred to as a "tour" housed in a wall of a charitable institution, ${ }^{6}$ these tours were collectively referred to as Foundlings Homes (Euvre des Enfants Trouves). ${ }^{7}$ The crib had a bell that would be rung by the mother after placing the child in it. ${ }^{8}$ The tour is then pivoted by a

\footnotetext{
${ }^{1}$ https://treaties.un.org/Pages/ViewDetails.aspx?mtdsg_no=IV-11\&chapter=4\&lang=en accessed on 10 March 2015 at 10:26 am; U.N Convention on the Rights of the Child (full text).

${ }^{2}$ Attiah (2014).

${ }^{3}$ Odievre v. France Application no. 42326/98 Strasbourg European Court of Human Rights 13

February 2003.

${ }^{4}$ Ibid note 3.

${ }_{6}^{5}$ Ibid note 2.

${ }^{6}$ Odievre v. France Application no. 42326/98 Strasbourg European Court of Human Rights 13 February 2003, page 6 .

${ }^{7}$ Ibid.

${ }^{8}$ Ibid.
} 
person stationed on the other side of the wall and the child is immediately removed to safety. ${ }^{1}$ The main motivation behind these tours for Saint Vincent de Paul was to prevent infanticide, abortion and babies being left in harsh conditions that could possibly lead to their deaths. ${ }^{2}$

The Revolution saw the introduction of free medical care to mothers who wished to abandon their children anonymously. This was later abolished and replaced with the open office or bureau overt system. ${ }^{3}$ The main difference between the new system and the Foundlings Home was that now women could be given information about the consequences of relinquishment of parental rights and could be offered some form of assistance. ${ }^{4}$

The current French law ${ }^{5}$ sees a great improvement on the law from the time of its primitive implementation; it allows access by adopted persons and people in state care to information about their origins (with the birth mother's consent). ${ }^{6}$

The very first baby safes in the United States were only introduced in 1999, beginning in Texas, after thirteen newborn babies were discarded in rubbish dumps and doorsteps over a period of twelve months, whereas the usual number over the same period was only one or two. ${ }^{7}$ It was therefore clear that a better method of prevention was urgently needed. The sponsors of such legislation argued that it would reduce unsafe infant abandonment. Representative Geanie Morrison introduced Texas' safe haven legislation as House Bill 3423, which was enacted on July 15, 1999 and to date all 50 states have enacted the same legislation. ${ }^{8}$ In the original legislation an infant of up to 30 days old may be left with a designated medical emergency infant care provider without fear of prosecution for abandonment or neglect. However, different states have different age limits for the infant and also have varying provisions regarding where an infant may be relinquished. ${ }^{9}$ The Texas Family code has since been amended to provide that the child may be up to 60 days old. ${ }^{10}$

\section{Termination of the Birth Parents' Rights and the Guarantee of Anonymity}

In the U.S there is no automatic termination of filiation. Filiation still exists between the mother and the child until the court is approached upon petition and this usually happens prior to the child entering a pre-adoptive home. Prior to approaching the court to place the child up for adoption the police or law enforcement agency will check whether this child has been reported as missing

\footnotetext{
${ }^{1}$ Ibid.

${ }^{2}$ Ibid.

${ }^{3}$ Ibid; Lefaucheur (2004), p. 321.

${ }^{4}$ Ibid note 1, page 6-9; Ibid note 6, page 321-327.

${ }^{5}$ No. 2002-93 of 22 January 2002.

${ }^{6}$ Ibid note 1, page 9; Ibid note 6, page 325-326.

${ }^{7}$ Neal (2012), page 352; Dreyer (2003) Vol 12. Page 171.

${ }^{8}$ Neal (2012), page 352; Dreyer (2003), Vol. 12, page 172.

${ }^{9}$ Texas Penal Code section 22.014(h)

${ }^{10}$ Texas Family Code section 262.302(a) 2015. "Accepting possession of certain abandoned children".
} 
and some are even required to check a putative father registry. ${ }^{1}$ However, similarly to France, in 17 states in the U.S and Puerto Rico, the act of surrendering an infant to a safe haven is presumed to be a relinquishment of parental rights and no further parental consent is required for the child's adoption. ${ }^{2}$

Certain states expressly guarantee the parent's anonymity by statute and safe haven providers cannot compel the parent or agent of the parent to provide identifying information. ${ }^{3}$ In the Texas Family Code section 262.302(b) the parent may be given a form for voluntary disclosure of the child's medical facts and history. Most states provide protection from criminal liability for parents who safely relinquish their infants while in other states, safe relinquishment is regarded as an affirmative defense in any prosecution. ${ }^{4}$

In France, the right to confidentiality enjoys statutory protection and carries with it a legitimate aim, i.e. alleviating the distress of mothers who do not have the means of bringing up their children and to encourage women to give birth in favourable conditions rather than alone with the risk that they may not tend to their children's needs. ${ }^{5}$ In terms of French law at the time of her delivery a mother mother may demand that the secret of her admission and of her identity be preserved. The right to give birth secretly in France is called "accouchement sous $X$ " (delivery under the name of ' $X$ ') because the woman's name is replaced in the child's file by an " $x$ ". 6 In terms of this legal provision women are able to give birth anonymously and free of charge and with the assurance that their identities will never be revealed to the child without their consent. ${ }^{7}$ The children thus have no filiation at birth. ${ }^{8}$

There are several options available to women who give birth in secret in France. ${ }^{9}$ Firstly, the initial birth certificate can be annulled and replaced with a new one within 3 working days should the mother change her mind and no longer wish to remain anonymous. ${ }^{10}$ If filiation has already been established the mother has the option of either handing the child over to the state Aide Sociale à l'Enfance (child welfare authority, ASE) or to a private adoption agency (Organisme Autorisé pour l'Adoption, OAA). ${ }^{11} \mathrm{~A}$ mother wishing to give her baby up for adoption will sign a consent form and will have a period of two months within which to change her mind. ${ }^{12}$

\footnotetext{
${ }^{1}$ Infant Safe Haven Laws, Child Welfare Information Gateway Current through February 2013 http:www.childwelfare.gov accessed on 11 May 2015.

${ }^{2}$ Ibid.

${ }^{3}$ Ibid.

${ }^{4}$ Ibid

${ }^{5}$ Odievre v. France Application no. 42326/98 Strasbourg European Court of Human Rights 13 February 2003, page 21.

${ }^{6}$ Villeneuve-Gokalp (2011), page 131.

${ }^{7}$ Ibid.

${ }^{8} \mathrm{Ibid}$.

${ }^{9}$ Ibid .

${ }^{10}$ Ibid, page 133.

${ }^{11}$ Ibid, ibid. .

${ }^{12}$ Ibid, ibid.
} 
A woman also has the option to disclose her name to the hospital staff but request that it not be displayed on the birth certificate. ${ }^{1}$ There is still no filiation established in this instance. The biological father may claim the child as his own on condition that his paternity is recognised prior to the child being placed for adoption. $^{2} \mathrm{~A}$ woman can be requested to leave her name in a sealed envelope and the child may request the information in that envelope to be revealed to the child at the age of majority. This is done through the CNAOP (National Council for Access to Personal Origins), which first contacts the birthmother for her permission. All women are requested to leave non-identifying information to which the child will always have access. ${ }^{3}$

\section{The Relinquishment of an Infant}

An infant in the United States may be relinquished, depending on the state, to any hospital, an emergency medical services provider, a health-care facility, fire station, police station, medical personnel responding to 911 emergency calls as well as to personnel at a church. ${ }^{4}$ The safe haven provider is required to accept emergency protective custody of the infant and to provide any immediate medical care that the infant may require. ${ }^{5}$ When the safe haven provider is not a hospital, the infant must be transferred to a hospital as soon as possible ${ }^{6}$ and the child welfare department must be notified that an infant has been relinquished. ${ }^{7}$ As previously stated some states accept infants 72 hours or younger and others accept infants that are up to one month or even one year old. ${ }^{8}$

According to French law the mother may give birth anonymously at a hospital free of charge and thereafter leave her baby with hospital staff where this legally abandoned child becomes a Pupilles de l'Etat - wards of the state and the adoption is arranged and consented to by social state welfare. ${ }^{9}$

The Importance of the Child's Right to know his or her Origins vs the Child's Right to Life

The U.S, which has not ratified the United Nations Convention on the Rights of the Child, does not entertain the argument on conflicting rights but rather takes

\footnotetext{
${ }^{1}$ Ibid, ibid.

${ }^{2}$ Ibid, page 134.

${ }^{3}$ French Law of 22 January 2002 on "access by adopted persons and people in State care to information about their origins" allows arrangements to be made for disclosure of identity subject to the mother's and the child's express consent being obtained. Therefore this law passed attempts to reconcile this right with the UN Convention on the Rights of the Child. French Law has permitted that either non-identifying information about his or her origins be given to a child of eighteen or that the birth giver's identity be made known when she has agreed.

${ }^{4}$ Infant Safe Haven Laws, Child Welfare Information Gateway Current through February 2013 http:www.childwelfare.gov accessed on 11 May 2015.

${ }^{5}$ Infant Safe Haven Laws, Child Welfare Information Gateway Current through February 2013 http:www.childwelfare.gov accessed on 11 May 2015.

${ }^{6}$ Ibid.

${ }^{7}$ Ibid.

${ }^{8}$ Ibid.

${ }^{9}$ Willenbacher (2004), pages 343-354.
} 
a firm stance in its focus on protecting the lives of newborns. ${ }^{1}$ I agree with this approach, as entertaining the lines of argument (dealt with below) may lead to a blurring of the real dire situation of newborns that are left beside the road.

In France, this debate has been ongoing. There exist two conflicting rights when it comes to anonymous birth. Article 6 of the United Nations Convention of the Rights of the Child guarantees the child's right to life whereas 7 and 8 details the child's right to know its parents and enjoy family ties. ${ }^{2}$

The arguments against anonymous birth are mainly psychological and political. $^{3}$ Many fear that not knowing the identity of one's birth parents will cause great moral suffering and will stifle the shaping of one's identity. ${ }^{4}$ They go onto to argue that anonymous birth shows no respect or consideration for the rights of the birth fathers, ${ }^{5}$ that it prevents legal control regarding lineage; that it ignores the obligations of biological mothers and the rights of children to know their origins. ${ }^{6}$ In short, protestors against the right to anonymous birth claim that it it infringes upon the rights guaranteed in Articles 7 and 8.

It is important, before engaging in this argument, first of all to look at the history of Article 7 and 8 of the Convention. These Articles were developed to deal with the problems of children trapped in war stricken countries, albeit the U.N has since stated that it may be interpreted more broadly. ${ }^{7}$ The creation of international law, particularly Article 8, as sponsored by Argentina, was effected during the military dictatorship of Argentina in 1975 and $1983 .^{8}$ Evidently the need for its inclusion was to benefit very specific situations as illustrated above. Article 7 and 8 were not designed to supersede the right to life, but to enhance or supplement the protection afforded by the right to life in Article 6.

The reality is that mothers are abandoning their babies in drains, sewerage pipes and dustbins because the pregnancy is unwanted, or is seen as a burden, or because the mother may find herself unable to abort either due to a moral dilemma or due to the fact that the pregnancy has progressed too far.

"[In any event] No society should in the name of the promotion of human rights be forced to leave a woman with abortion as the only apparent safe option.",

This leaves a woman with only two options; firstly to commit neonaticide or to abandon the baby in a place that will endanger the life of that child. Both of these situations occur after a clandestine delivery. Society's emotions are caught up in the emphasis that is seemingly placed on the rights of the mother rather than

\footnotetext{
${ }^{1}$ Ibid note 1 .

${ }^{2}$ United Nations Convention on the Rights of the Child 1990, Vol 1577, I-27531.

${ }^{3}$ Lefaucheur (2004), page 328.

${ }^{4}$ Ibid, page 328.

${ }^{5}$ Ibid, page 330 .

${ }^{6}$ Ibid, page 352 .

${ }^{7}$ O’ Donovan (2002), page 351.

${ }^{8}$ Ibid, page 352 .

${ }^{9}$ Odievre v. France Application no. 42326/98 Strasbourg European Court of Human Rights 13 February 2003, page 38 concurring judgment of Judge Greve.
} 
the child. ${ }^{1}$ Clandestine delivery clearly shows us that both lives are at risk. As stated by Judge Greve: ${ }^{2}$

"[The] point is that the pregnant woman remains adamant that she will not opt for safe labour if access to medical services is linked inextricably to her having to renounce her anonymity."

Anonymous birth fills the gap created by the law in that it allows a woman, who does not want to abort her baby because she wants that baby to live, not necessarily with her as the parent, to safely relinquish that baby knowing that it will be cared for and that she will not be prosecuted for such abandonment. The anonymity aspect is the main driving factor for this system; it has even been referred to as the "bait" of the safe haven concept. ${ }^{3}$ It is more likely that parents will make use of this system only with the guarantee of their right to anonymity. ${ }^{4}$ Women who exercise the right to anonymous birth often hide their pregnancies from family and or the community around them. They are in a state of denial, denying the fact of the pregnancy due to shame; a lack of support (both emotionally and financially) and various other factors. These women do not consider adoption as an option as that would entail revealing their identities and dealing with the judgment of that decision from family members. In order to avoid the moral responsibility of such birth, the woman would rather resort to legal or illegal abortion. ${ }^{5}$

The anonymity aspect has come under a lot of scrutiny, however, as stated by Judge Ress and Judge Kuris: ${ }^{6}$

"Persons who seek disclosure at any price, even against the express will of their natural mother, must ask themselves whether they would have been born had it not been for the right to give birth anonymously."

The other aspect of anonymous birth, the importance of which cannot be overemphasized, is the assurance that these women will be immune from prosecution. If the woman thought that she was going to be prosecuted anyway then she would prefer to resort to illegal and concealed methods of birth and abandonment. In the U.S, some states provide total immunity from prosecution, whereas other states provide an affirmative defense in prosecution proceedings. France provides complete immunity from liability for the woman who chooses the option to give birth anonymously at a hospital.

\footnotetext{
${ }^{1}$ Neal (2012), page 357.

${ }^{2}$ Ibid note 3, page 37.

${ }^{3}$ Dreye (2003), Vol. 12, page 172.

${ }^{4}$ Ibid, page 180 .

${ }^{5}$ Odievre v. France Application no. 42326/98 Strasbourg European Court of Human Rights 13 February 2003, page 33 concurring judgment of Judge Ress and Judge Kuris.

${ }^{6}$ Odievre v. France Application no. 42326/98 Strasbourg European Court of Human Rights 13

February 2003, page 33.
} 
The court recognised in Odievre $v$ France ${ }^{1}$ that the right to life is superior to any other right; it is seen as the struggle against neonaticide, infanticide, abortion, unsupervised delivery or abandonment, and all other rights are about giving quality to that very life. ${ }^{2}$ The primary interest of that child is to be born and not to be born in circumstances where its health is put under unnecessary risk because the mother, in order to maintain secrecy, is deprived of professional assistance when in labour. ${ }^{3}$

As for depriving the child of a right to identity, many compromises have been reached both in the U.S and in France where each country has developed a system of voluntary disclosure. France has even gone so far as creating a body called the National Council for Access to Personal Origins (CNAOP) to assist a child born of $\mathrm{x}$ to find out information about the birth mother, with the birth mother's consent. ${ }^{4}$

In the U.S certain steps have also been developed to locate the father of the child. The authorities first ensure that the child is not listed as a missing child and secondly a putative father registry is also checked. ${ }^{5}$

\section{The Laws Applicable to Baby Safes and Anonymous Births with a Specific Look at South African Legislation and its Effects}

South Africa ratified the UN Convention on the Rights of the Child on the $16^{\text {th }}$ of June 1995.

The previous Child Care Act of $1983^{6}$, Section 50 states:

"(1) Any parent or guardian of a child or any person having the custody of a child who-

(a) Ill-treats that child or allows it to be ill-treated;

or

(b) Abandons that child, shall be guilty of an offence."

The current Children's Act of $2005^{7}$, section 305, which deals with offences, states that the parent, guardian or other person having parental rights and responsibilities, care-giver, or person who voluntarily cares for a child whether indefinitely, temporarily or partially is guilty of an offence if that parent or caregiver or other person - subsection (3)(b) - abandons the child. Furthermore, this person may be held liable as expressed in subsection (6) and (7) to a fine or imprisonment not exceeding ten or 20 years respectively or to both a fine and imprisonment.

\footnotetext{
${ }^{1}$ Ibid page 37.

${ }^{2}$ Lefaucheur (2004), page 329; Dreyer (2003), Vol. 12, page 172.

${ }^{3}$ Ibid note 1, page 37 concurring judgment of Judge Greve.

${ }^{4}$ Dreyer (2003), Vol. 12, page 180; Lefaucheur (2004), page 325; Villeneuve-Gokalp (2011), page 134.

${ }^{5}$ Dreyer (2003), Vol. 12, page 181.

${ }^{6}$ Child Care Act 74 of 1983.

${ }^{7}$ Children's Act 38 of 2005.
} 
The crime of abandonment is also mentioned in the General Law Amendment Act 46 of 1935, section 113 (as amended by the Judicial Matters Amendment Act of $2008^{1}$ ) defines the disposing of the body of a newborn, even though it is not proven that the child in question died before its body was disposed of, as the crime of concealment of birth. Mothers face conviction of a fine or imprisonment not exceeding three years and in some instances mothers are charged with the crime of attempted murder.

These laws do not serve as a deterrent for desperate mothers who feel they have no other option than abandoning their infants in places that endanger the lives of newborns with 70 percent of the sites of abandonment cited as unsafe. ${ }^{2}$ Of the 200 abandoned babies found in Soweto and Johannesburg monthly, only 60 are found alive. ${ }^{3}$

South African legislation is solely reactionary, in that it deals specifically with the issue of child abandonment and the consequences that will be faced by the mother of the abandoned child, as opposed to being preventative by enacting legislation that will provide a solution.

These women should have the right to apply the provisions of Article 6 of the Convention in terms of which "state parties shall ensure to the maximum extent possible the survival and development of the child,"which trusts that the state will actually do so. Article 6 is the main driving point behind baby safe haven laws. Although clearly the best option available, its success in the mentioned countries is not easily quantified, first due to the lack of awareness of the laws on this issue in the respective countries and secondly because of the difficulty in many countries to establish exactly which women are using these laws, largely due to the secrecy element. Nevertheless, as correctly stated by author Brittany Neal "... even one case where a safe haven was taken advantage of bodes success."4

\section{Conclusion}

Having analyzed the position in both a convention as well as a nonconvention country, it is clear that the U.N Convention does not serve as a hindrance to women who want to relinquish their parental rights but rather (Article 6 of the Convention) promotes the implementation of these baby safe haven laws. The right to life far outweighs the child's right to an identity. Further delay of the implementation of these laws will cause further loss of lives. Women need a solution that is better than the ones currently available to them. They are in need of a solution that not only guarantees the survival of their babies but that also protects them from prosecution. The social imagery of the abandoning mother depicts a woman oppressed by the baby's father or their families; tormented by

\footnotetext{
${ }^{1}$ Judicial Matters Amendment Act 66 of 2008.

2 Blackie, Dee of the National Adoption Coalition Fact Sheet on Child Abandonment Research in South Africa, 20 May 2014 with reference to an article in The Star Newspaper 2 May 2012.

${ }^{3}$ Ibid.

${ }^{4}$ Neal (2012), page 358.
} 
rape, incest or forced prostitution; ${ }^{1}$ living in extreme poverty or living with her parents. The shame of the pregnancy proves to be too onerous to risk exposure. Therefore, an imposition of stricter requirements on the system of anonymous birth, such as compelling the mother to leave her identifying information, will defeat the entire purpose of this system - to allow women an alternative other than abortion and infanticide (which both leave mothers unidentified) and to take away the shame of pregnancy and birth in the circumstances faced by these women.

"It is better to have a baby delivered safely to a designated provider with no medical history than it is to find this same baby discarded in the trash."2

\section{References}

Blackie, Dee of the National Adoption Coalition, Fact Sheet on Child Abandonment Research in South Africa, 20 May 2014.

Child Care Act 74 of 1983.

Children's Act 38 of 2005.

Dreyer, S. 2003. Texas' Safe Haven Legislation: Is Anonymous, Legalized Abandonment a Viable Solution to Newborn Discardment and Death? Texas Journal of Women and the Law, Volume 12.

Infant Safe Haven Laws, Child Welfare Information Gateway Current through February 2013 Available at http://www.childwelfare.gov accessed on 11 May 2015.

Judicial Matters Amendment Act 66 of 2008.

Attiah, K. Deputy Digital Editor of the Washington Post 21 November 2014. Available at http://www.washingtonpost.com/.../why-wont-the-u-s-ratify-the-u-n-s-child-right accessed on 10 March 2015.

Lefaucheur, N., 2004. “The French 'tradition' of anonymous birth: The lines of argument. International Journal of Law, Policy and the Family 18.

Neal, B. 2012. Reforming the safe haven in Ohio: Protecting the rights of mothers through anonymity, Journal of Law and Health Volume 25:347.

Odievre v France Application no. 42326/98 Judgment Strasbourg European Court of Human Rights 13 February 2003.

O' Donovan, K. 2002. Real Mothers for Abandoned Children. Law Society Review, Volume 36:2.

Texas Family Code section 262.302(a) 2015. "Accepting possession of certain abandoned children".

Texas Journal of Women and the Law, Volume 12.

Texas Penal Code section 22.014(h)

United Nations Convention on the Rights of the Child 1990, Volume 1577, I-27531.

U.N. Convention on the Rights of the Child (full text), Available at https://treaties.un.org/Pages/ViewDetails.aspx?mtdsg_no=IV-

$11 \&$ chapter=4\&lang=en accessed on 10 March 2015 at 10:26 am.

Villeneuve-Gokalp, C. 2011. 'Women who give birth "secretly" in France 2007-2009', Population-E, 66(1).

\footnotetext{
${ }^{1}$ Willenbacher (2004), pages 343-354.

${ }^{2}$ Dreyer (2003), Vol. 12, page 180.
} 
Willenbacher, B. 2004. Legal Transfer of French Traditions? German and Austrian Initiatives to Introduce Anonymous Birth. International Journal of Law, Policy and the Family 18, 343-354. 
